\title{
A cross-sectional survey exploring attitudes towards provincial electronic health record implementation among clients attending the Provincial Sexually Transmitted Infections Clinic in British Columbia
}

\author{
Heather Pedersen, ${ }^{1}$ Darlene Taylor, ${ }^{1}$ Mark Gilbert, ${ }^{2}$ Melanie Achen, ${ }^{1}$ Richard Lester, ${ }^{2}$ \\ Gina Ogilvie ${ }^{1,2}$
}

${ }^{1}$ Clinical Prevention Services, BC Centre for Disease Control, Vancouver, British Columbia, Canada

${ }^{2}$ School of Population and Public Health, University of British Columbia, Vancouver, British Columbia, Canada

\section{Correspondence to} Heather Pedersen, Clinical Prevention Services, BC Centre for Disease Control, $655 \mathrm{~W}$ 12th Ave, Vancouver, BC V5Z 4R4, Canada;

heather.pedersen@bccdc.ca

Received 13 Auqust 2014 Revised 7 October 2014 Accepted 10 October 2014 Published Online First

5 December 2014

\section{CrossMark}

To cite: Pedersen $\mathrm{H}_{\text {, }}$ Taylor D, Gilbert M, et al. Sex Transm Infect 2015:91:44-48.

\section{ABSTRACT \\ Introduction To support control of sexually} transmitted infections (STI), British Columbia is exploring data sharing through a provincial electronic health record (EHR). Increased electronic data sharing among healthcare providers may be a barrier for clients of STI clinics where expectations of privacy and confidentiality are heightened.

Methods A survey to assess attitudes towards sharing of personal health information through a provincial EHR was conducted with a convenience sample of clients attending an STI clinic in Vancouver. Descriptive statistics and logistic regression were used to examine the association between the primary outcome variable, whether a client would be less likely to take the test for an STI or HIV if their clinic records were made part of a provincial EHR, and independent variables of interest.

Results A total of 1004 clients completed the survey, and $31 \%$ stated that they would be less likely to get tested for STI/HIV if their records were made part of a provincial EHR. Participants who were more likely to agree that they might avoid testing had the expectation that no other clinician would review their chart (adjusted $O R(A O R)=3.55)$, or expected their records would not be shared beyond the clinic $(A O R=2.81)$.

Discussion While most participants thought an EHR was acceptable, a large minority expressed that they might avoid testing if their records were made part of a provincial EHR. The introduction of a provincial EHR should be considered with caution in STI healthcare settings to ensure that screening, case detection and treatment are not negatively impacted.

\section{INTRODUCTION}

Infectious diseases are emerging and spreading faster than ever before. ${ }^{1}$ The 2003 outbreak of Severe Acute Respiratory Syndrome and the Naylor Report that followed its successful containment solidified Canada's commitment to enhanced infectious disease control. ${ }^{2}$ An electronic health record (EHR) is a digital version of a patient's medical chart at a clinical setting. ${ }^{3}$ EHRs have been gradually adopted in Canada, and uptake is growing rapidly due to potential for cost savings, improved workflow, improved patient care management and the ability to share data. ${ }^{3-5}$ Increasingly, EHR systems extend beyond individual clinical settings to regional, provincial and national levels. This facilitates public health management of diseases through enhanced surveillance, analysis and reporting. Through the Canada Health Infoway initiative, the Canadian government is investing in improved health information system technology such as Panorama, a national public health surveillance system. $^{67}$ In British Columbia (BC), Panorama will support communicable disease control through linkages to provider, client and Provincial Laboratory registries. ${ }^{8}$ Given the shift towards increased electronic information sharing in health systems, considerations of patient and public perspectives of EHR adoption are critical to address concerns and misconceptions around privacy and confidentiality, data security and access to records. ${ }^{9-11}$

Increasing uptake of sexual health services is an important public health strategy to prevent and control the spread of sexually transmitted infections (STI). ${ }^{12} 13$ Practitioners at sexual health clinics possess specialised skills and training to provide dedicated STI services, making them an important alternative to primary care settings. ${ }^{14} 15$ Privacy and health information exchange may be of particular concern to patients accessing sexual health services, where the process of STI testing can often elicit emotions of embarrassment, stigma or guilt. ${ }^{16} 17$ Clients who choose to attend clinics that exclusively deal with STIs often have the expectation of receiving non-judgemental care where information is not shared beyond the clinic without consent. ${ }^{18} 19$ Barriers to access of these services could increase non-attendance for STI testing and diagnosis which could impact the rising incidence of STIs in Canada. ${ }^{20}$ For this reason, we conducted a study aimed at exploring the attitudes of clients towards EHR implementation in an STI clinic setting and to determine if use of a provincial EHR would impact acceptability and intention to be screened for STIs.

\section{METHODS}

This cross-sectional survey was conducted at the BC Centre for Disease Control (BCCDC) Provincial STI clinic where a confidential and anonymous client satisfaction survey is routinely offered. The BCCDC Provincial STI clinic is located in Vancouver, BC, and offers clients free, confidential testing and treatment for STIs and HIV. Services such as STI assessment, diagnosis and treatment are provided by nurses with certified 
practice in Reproductive Health-STI from the College of Registered Nurses of BC, in collaboration with STI physician specialists. The clinic sees over 15000 encounters annually for services, including STI/HIV testing and treatment, phone consultation, provision of results and contact tracing.

Between July 2012 and March 2013, a survey was offered to all clients presenting to the BCCDC STI clinic until 1000 surveys were submitted. The self-administered survey included 10 questions on a five-point Likert scale that were designed to explore client knowledge, attitudes and beliefs towards health information exchange related to a provincial EHR within an STI clinic setting based on the principles of the Theory of Planned Behaviour. ${ }^{21}$ Currently, clinical data are kept on an internal EHR that is not shared beyond the BCCDC. Descriptive statistics, bivariate analysis, and logistic regression were performed using SPSS software for Windows (V.14.0). Clients were given a consent form prior to completing the survey, which included a brief introduction to EHR which read: 'In the future, British Columbia will have an electronic health record system. This would mean that patient health records will be electronic, and licensed health practitioners may be able to review a patient`s health record including visits for STI and HIV testing. Patients will be able to apply to have their records kept private.' Responses to all survey questions were dichotomised to 'Agree' (strongly agree or agree) or 'Disagree/Neutral' (neutral, disagree and strongly disagree) to facilitate interpretation of the analysis. The primary variable of interest was the response to the question 'I would be less likely to test for STI/HIV if my health records were made part of a provincial EHR' which was dichotomised to 'Agree' or 'Disagree/Neutral'. Independent variables included demographic information and the responses to the other nine survey questions which were dichotomised in a similar manner.

A descriptive analysis of demographic information and responses to survey questions was performed. $\chi^{2}$ Or Fisher's exact analyses were conducted to compare characteristics of those who agreed that they would be less likely to test if health records were made part of the provincial EHR with those who disagreed. Logistic regression was used to model the association between the odds of testing for an STI/HIV and variables of interest, with the odd ratios and associated CIs used as the measure of association. As this was an exploratory analysis, all variables in the bivariate analysis that reached significance of $\mathrm{p}<0.2$ were offered for inclusion in the multivariate model. ${ }^{22}$ Backwards stepwise likelihood ratio method was used for logistic regression to achieve the best-fitting model.

\section{RESULTS}

A total of 1004 clients completed the survey. Descriptive statistics for demographic factors are displayed in table 1 and responses to survey questions in table 2. We compared demographic factors of survey participants with all clients who attended the clinic during the study period and found no statistically significant differences (data not shown). From the descriptive analysis, $31.6 \%$ of participants agreed, or strongly agreed, that they would be less likely to get tested for STIs and HIV if their personal health records from their clinic visit were

Table 1 Descriptive statistics and bivariate analysis of demographic factors comparing participants who agreed versus disagreed/neutral with being less likely to test for STIs and HIV if health records were made part of the provincial EHR*

\begin{tabular}{|c|c|c|c|c|c|}
\hline \multirow[b]{2}{*}{ Variable } & \multirow[b]{2}{*}{ Variable level } & \multirow[b]{2}{*}{$\begin{array}{l}\text { Total } \\
\mathrm{N}(\%)\end{array}$} & \multicolumn{3}{|c|}{$\begin{array}{l}\text { Less likely to test for STI/HIV if health records were made } \\
\text { part of provincial EHR }\end{array}$} \\
\hline & & & $\begin{array}{l}\text { Disagree/neutral } \\
\mathrm{N}(\%)\end{array}$ & $\begin{array}{l}\text { Agree } \\
\mathrm{N}(\%)\end{array}$ & p Value \\
\hline Gender & $\begin{array}{l}\text { Female } \\
\text { Male } \\
\text { Transgender }\end{array}$ & $\begin{array}{c}368(38.3) \\
588(61.3) \\
4(0.4)\end{array}$ & $\begin{array}{r}270(74.2) \\
378(65.1) \\
3(75.0)\end{array}$ & $\begin{array}{r}94(25.8) \\
203(34.9) \\
1(25.0)\end{array}$ & 0.008 \\
\hline Sexual orientation & $\begin{array}{l}\text { Heterosexual } \\
\text { Homosexual } \\
\text { Bisexual }\end{array}$ & $\begin{array}{c}799(83.3) \\
89(9.3) \\
71(7.4)\end{array}$ & $\begin{array}{r}547(69.2) \\
57(65.5) \\
46(65.7)\end{array}$ & $\begin{array}{r}244(30.8) \\
30(34.5) \\
24(34.3)\end{array}$ & 0.65 \\
\hline Age group & $\begin{array}{l}14-18 \\
19-29 \\
30-39 \\
40-49 \\
50-59 \\
>59\end{array}$ & $\begin{array}{c}3(0.3) \\
384(40.0) \\
341(35.5) \\
118(12.3) \\
89(9.3) \\
26(2.7)\end{array}$ & $\begin{array}{r}2(66.7) \\
285(75.0) \\
239(71.1) \\
65(55.6) \\
46(52.3) \\
15(57.7)\end{array}$ & $\begin{array}{l}1(33.3) \\
95(25.0) \\
97(28.9) \\
52(44.4) \\
42(47.7) \\
11(42.3)\end{array}$ & $<0.001$ \\
\hline Ethnic group & $\begin{array}{l}\text { Aboriginal } \\
\text { Arab } \\
\text { Caucasian/white } \\
\text { South Asian } \\
\text { Asian } \\
\text { Black/African } \\
\text { Hispanic } \\
\text { Other }\end{array}$ & $\begin{array}{c}27(2.8) \\
6(0.6) \\
695(72.9) \\
33(3.5) \\
128(13.4) \\
16(1.7) \\
27(2.8) \\
22(2.3)\end{array}$ & $\begin{array}{r}19(70.4) \\
5(83.3) \\
485(70.4) \\
20(60.6) \\
79(62.2) \\
12(80.0) \\
15(57.7) \\
13(65.0)\end{array}$ & $\begin{array}{r}8(29.6) \\
1(16.7) \\
204(29.6) \\
13(39.4) \\
48(37.8) \\
3(20.0) \\
11(42.3) \\
7(35.0)\end{array}$ & 0.38 \\
\hline First language & $\begin{array}{l}\text { English } \\
\text { Non-English }\end{array}$ & $\begin{array}{l}815(85.1) \\
143(14.9)\end{array}$ & $\begin{array}{r}563(69.9) \\
87(61.7)\end{array}$ & $\begin{array}{r}243(30.1) \\
54(38.3)\end{array}$ & 0.05 \\
\hline Highest level of education & $\begin{array}{l}\text { No formal education } \\
\text { Elementary or junior high school } \\
\text { High school } \\
\text { College/trade school } \\
\text { University } \\
\text { Other (ie, graduate school) }\end{array}$ & $\begin{array}{c}0 \\
12(1.3) \\
123(12.9) \\
269(28.2) \\
541(56.7) \\
9(0.9)\end{array}$ & $\begin{array}{r}0 \\
7(63.6) \\
86(71.1) \\
184(69.2) \\
364(67.8) \\
8(88.9)\end{array}$ & $\begin{array}{r}0 \\
4(36.4) \\
35(28.9) \\
82(30.8) \\
173(32.2) \\
1(11.1)\end{array}$ & 0.70 \\
\hline
\end{tabular}

EHR, electronic health record; STI, sexually transmitted infection. 
Table 2 Descriptive statistics and bivariate analysis of survey question responses comparing participants who agreed versus disagreed/neutral with being less likely to test for STIs and HIV if health records were made part of the provincial EHR*

\begin{tabular}{|c|c|c|c|c|c|}
\hline \multirow[b]{2}{*}{ Survey question } & \multirow[b]{2}{*}{ Response } & \multirow[b]{2}{*}{$\begin{array}{l}\text { Total } \\
\mathrm{N}(\%)\end{array}$} & \multicolumn{3}{|c|}{$\begin{array}{l}\text { Less likely to test for STI/HIV if } \\
\text { health records were made part of } \\
\text { provincial EHR }\end{array}$} \\
\hline & & & $\begin{array}{l}\text { Disagree/ } \\
\text { neutral } \\
\mathrm{N}(\%)\end{array}$ & $\begin{array}{l}\text { Agree } \\
\mathrm{N}(\%)\end{array}$ & p Value \\
\hline $\begin{array}{l}\text { (a) I am currently satisfied that my name and identifying information are kept private when I test } \\
\text { at this clinic }\end{array}$ & $\begin{array}{l}\text { Disagree/neutral } \\
\text { Agree }\end{array}$ & $\begin{array}{l}138(13.9) \\
856(86.1)\end{array}$ & $\begin{array}{r}97(70.3) \\
571(68.4)\end{array}$ & $\begin{array}{r}41(29.7) \\
264(31.6)\end{array}$ & 0.65 \\
\hline $\begin{array}{l}\text { (b) It would be acceptable for my record from my visit to this clinic to be viewable by my family } \\
\text { physician }\end{array}$ & $\begin{array}{l}\text { Disagree/neutral } \\
\text { Agree }\end{array}$ & $\begin{array}{l}404(40.6) \\
591(59.4)\end{array}$ & $\begin{array}{l}213(54.1) \\
455(78.3)\end{array}$ & $\begin{array}{l}181(45.9) \\
126(21.7)\end{array}$ & $<0.001$ \\
\hline $\begin{array}{l}\text { (c) It would be acceptable for my EHR from my visit at the provincial STI clinic to be available } \\
\text { for my pharmacist to review }\end{array}$ & $\begin{array}{l}\text { Disagree/neutral } \\
\text { Agree }\end{array}$ & $\begin{array}{l}694(69.7) \\
301(30.3)\end{array}$ & $\begin{array}{l}435(63.9) \\
234(79.1)\end{array}$ & $\begin{array}{r}246(36.1) \\
62(20.9)\end{array}$ & $<0.001$ \\
\hline $\begin{array}{l}\text { (d) It would be acceptable for my EHR from my visit at the provincial STI clinic to be available } \\
\text { for my medical specialist(s) to review }\end{array}$ & $\begin{array}{l}\text { Disagree/neutral } \\
\text { Agree }\end{array}$ & $\begin{array}{l}444(45.1) \\
541(54.9)\end{array}$ & $\begin{array}{l}246(56.0) \\
423(79.1)\end{array}$ & $\begin{array}{l}193(44.0) \\
112(20.9)\end{array}$ & $<0.001$ \\
\hline $\begin{array}{l}\text { (e) It would be acceptable for my EHR from my visit at the provincial STI clinic to be available } \\
\text { for nurses in other STI clinics to review }\end{array}$ & $\begin{array}{l}\text { Disagree/neutral } \\
\text { Agree }\end{array}$ & $\begin{array}{l}412(41.8) \\
574(58.2)\end{array}$ & $\begin{array}{l}235(58.0) \\
431(75.6)\end{array}$ & $\begin{array}{l}170(42.0) \\
139(24.4)\end{array}$ & $<0.001$ \\
\hline $\begin{array}{l}\text { (f) It would be acceptable for my EHR from my visit at the BCCDC STI clinic to be available for } \\
\text { public health nurses who follow-up positive test results to review }\end{array}$ & $\begin{array}{l}\text { Disagree/neutral } \\
\text { Agree }\end{array}$ & $\begin{array}{l}357(36.2) \\
629(63.8)\end{array}$ & $\begin{array}{l}206(58.5) \\
462(73.9)\end{array}$ & $\begin{array}{l}146(41.5) \\
163(26.1)\end{array}$ & $<0.001$ \\
\hline $\begin{array}{l}\text { (g) I would be less likely to test for STI/HIV if my health records were made part of } \\
\text { a provincial EHR }\end{array}$ & $\begin{array}{l}\text { Disagree/neutral } \\
\text { Agree }\end{array}$ & $\begin{array}{l}671(68.4) \\
310(31.6)\end{array}$ & & & \\
\hline $\begin{array}{l}\text { (h) When getting care at the BCCDC STI clinic, it is my expectation that no other clinicians in the } \\
\text { province will be able to review my chart from my visit }\end{array}$ & $\begin{array}{l}\text { Disagree/neutral } \\
\text { Agree }\end{array}$ & $\begin{array}{l}463(47.1) \\
520(52.9)\end{array}$ & $\begin{array}{l}400(86.8) \\
269(52.4)\end{array}$ & $\begin{array}{r}61(13.2) \\
244(47.6)\end{array}$ & $<0.001$ \\
\hline $\begin{array}{l}\text { (i) One of the reasons I came for care at the BCCDC STI clinic is that I did not want records of } \\
\text { my encounter shared beyond this clinic }\end{array}$ & $\begin{array}{l}\text { Disagree/neutral } \\
\text { Agree }\end{array}$ & $\begin{array}{l}518(54.2) \\
437(45.8)\end{array}$ & $\begin{array}{l}441(86.0) \\
210(48.5)\end{array}$ & $\begin{array}{r}72(14.0) \\
223(51.5)\end{array}$ & $<0.001$ \\
\hline $\begin{array}{l}\text { (j) If I could test for HIV completely anonymously at this clinic (meaning no name or phone } \\
\text { number attached to my result), I would choose to test this way }\end{array}$ & $\begin{array}{l}\text { Disagree/neutral } \\
\text { Agree }\end{array}$ & $\begin{array}{l}533(56.2) \\
416(43.8)\end{array}$ & $\begin{array}{l}419(79.5) \\
228(55.1)\end{array}$ & $\begin{array}{l}108(20.5) \\
186(44.9)\end{array}$ & $<0.001$ \\
\hline
\end{tabular}

included in a provincial EHR. The majority $(86.1 \%)$ of participants stated they agreed, or strongly agreed, that they were satisfied with the clinic's current system of keeping their name and personal health information private. While most clients thought EHR was acceptable, a large proportion of participants indicated that they disagreed that it was acceptable for other health professionals to have access to their clinical records from the STI clinic, including family physician (40.6\%), pharmacist $(69.7 \%)$, medical specialist $(45.1 \%)$, nurses in other STI clinics (41.8\%) and public health nurses doing follow-up (36.2\%).

In the bivariate analysis, age, gender and first language were statistically significant between those who agreed that they would be less likely to test compared with those who did not, while sexual orientation, ethnic group and education were not significant factors (table 1). All survey questions related to attitudes towards information sharing through an EHR were found to be significantly associated with likeliness to test (table 2), except question (a) 'I am currently satisfied that my name and identifying information are kept private when I test at this clinic', which was not statistically significant $(p=0.65)$. As a result, this question was excluded from the multivariate analysis.

Six variables were kept in the final multivariate logistic regression model. Unadjusted and adjusted ORs for all six variables are provided in table 3. Participants who agreed that they were less likely to test for STIs were more likely to have the expectation that no other clinician in the province would be able to review their chart from the clinic (adjusted OR (AOR) $=3.55$ (95\% CI 2.43 to 5.20)) and more likely to agree to the statement 'One of the reasons I came for care at the BCCDC STI clinic is that I did not want records of my encounter shared beyond this clinic' (AOR=2.81 (95\% CI 1.92 to 4.12)). These clients were also more likely to agree that they would test anonymously for HIV at the clinic if they could $(\mathrm{AOR}=1.49$ (95\% CI 1.05 to 2.10)). Alternatively, participants who agreed that they would be less likely to test for STIs if their health record was made part of the provincial EHR were more likely to be men $(\mathrm{AOR}=1.66(95 \% \mathrm{CI} 1.18$ to 2.35$)$ ), were less likely to find it acceptable for their family physician to view their record $(\mathrm{AOR}=0.67$ (95\% CI 0.45 to 1.00$)$ ) and were less likely to find it acceptable for their medical specialist to have access to their encounter $(\mathrm{AOR}=0.70(95 \% \mathrm{CI} 0.47$ to 1.04$))$.

\section{DISCUSSION}

In this survey of STI clinic clients, although information sharing through a provincial EHR appeared to be acceptable to the majority of participants, a large minority said they would be less likely to test for an STI or HIV if their records were made part of a provincial EHR. This suggests that information exchange of sexual health records could deter some people from seeking STI and HIV testing. Participants who generally had negative attitudes towards other healthcare providers having access to their STI/HIV personal health information, or who had expectations that their records would not be shared beyond the clinic, were more likely to agree that they might avoid testing. From the multivariate analysis, participants who had the expectation that no other clinician would be able to review their chart, who did not want records of their encounter shared beyond this clinic, who were interested in testing anonymously for HIV, and men were more likely to agree that they might avoid testing. Participants who found it acceptable for their family physician or medical specialist to have access to their encounter may be less likely to avoid testing if a provincial EHR were implemented. Taken together, the results from this survey suggest that people who have heightened concerns around privacy and 
Table 3 OR estimates* for factors associated with being less likely to test for STIs if health records were made part of provincial EHR

\begin{tabular}{|c|c|c|c|c|c|c|}
\hline Variable & Variable level & $\begin{array}{l}\text { Unadjusted } \\
\text { OR }\end{array}$ & $95 \% \mathrm{Cl}$ & $\begin{array}{l}\text { Adjusted } \\
\text { OR }\end{array}$ & $95 \% \mathrm{Cl}$ & $\mathrm{p}$ Value \\
\hline \multirow[t]{2}{*}{ Gender } & Female & Reference & & Reference & & \\
\hline & Male & 1.54 & 1.15 to 2.06 & 1.66 & 1.18 to 2.35 & 0.004 \\
\hline $\begin{array}{l}\text { (b) It would be acceptable for my record from my visit to this clinic to be } \\
\text { viewable by my family physician }\end{array}$ & $\begin{array}{l}\text { Disagree/neutral } \\
\text { Agree }\end{array}$ & $\begin{array}{l}\text { Reference } \\
0.33\end{array}$ & 0.25 to 0.43 & $\begin{array}{l}\text { Reference } \\
0.67\end{array}$ & 0.45 to 1.00 & 0.05 \\
\hline $\begin{array}{l}\text { (d) It would be acceptable for my EHR from my visit at the provincial STI clinic } \\
\text { to be available for my medical specialist(s) to review }\end{array}$ & $\begin{array}{l}\text { Disagree/neutral } \\
\text { Agree }\end{array}$ & $\begin{array}{l}\text { Reference } \\
0.34\end{array}$ & 0.25 to 0.45 & $\begin{array}{l}\text { Reference } \\
0.70\end{array}$ & 0.47 to 1.04 & 0.08 \\
\hline $\begin{array}{l}\text { (h) When getting care at the BCCDC STI clinic, it is my expectation that no } \\
\text { other clinicians in the province will be able to review my chart from my visit }\end{array}$ & $\begin{array}{l}\text { Disagree/neutral } \\
\text { Agree }\end{array}$ & $\begin{array}{l}\text { Reference } \\
5.95\end{array}$ & 4.32 to 8.19 & $\begin{array}{l}\text { Reference } \\
3.55\end{array}$ & 2.43 to 5.20 & $<0.001$ \\
\hline $\begin{array}{l}\text { (i) One of the reasons I came for care at the BCCDC STI clinic is that I did not } \\
\text { want records of my encounter shared beyond this clinic }\end{array}$ & $\begin{array}{l}\text { Disagree/neutral } \\
\text { Agree }\end{array}$ & $\begin{array}{l}\text { Reference } \\
6.50\end{array}$ & 4.76 to 8.89 & $\begin{array}{l}\text { Reference } \\
2.81\end{array}$ & 1.92 to 4.12 & $<0.001$ \\
\hline $\begin{array}{l}\text { (j) If I could test for HIV completely anonymously at this clinic (meaning no } \\
\text { name or phone number attached to my result), I would choose to test this } \\
\text { way }\end{array}$ & $\begin{array}{l}\text { Disagree/neutral } \\
\text { Agree }\end{array}$ & $\begin{array}{l}\text { Reference } \\
3.16\end{array}$ & 2.38 to 4.22 & $\begin{array}{l}\text { Reference } \\
1.49\end{array}$ & 1.05 to 2.10 & 0.02 \\
\hline
\end{tabular}

confidentiality may be more likely to avoid testing for STIs or HIV should their records be made part of a provincial EHR.

Our findings concur with the findings of a recent study in New Zealand on the attitudes towards electronic record sharing in sexual health services where $31 \%$ said that they would prefer no other health professional to know about their attendance at clinic, and $47 \%$ of self-referred patients stated that confidentiality concerns were the main reason for attending. ${ }^{23}$ In their study, 31\% said that they would stop attending the clinic if discharge letters were sent to their general practitioner and 21\% said they would stop using the clinic if their personal health number was used on laboratory tests. ${ }^{23}$

In our study, there were no significant differences among those who were more likely or less likely to avoid testing with respect to sexual orientation, ethnicity and education. This might be a reflection of our study population, which primarily consisted of clients who were heterosexual, Caucasian, English-speaking, university educated and between the age of 19 and 39 years. There was also a relatively high non-response rate among demographic questions $(4.3 \%-5.5 \%)$ which may have affected our ability to detect significant differences. In the sexual health literature, clients with greater expectations of privacy and confidentiality often represent vulnerable populations such as youth and men who have sex with men (MSM). ${ }^{19} 2425$ In BC, youth and MSM also represent the highest transmission rates for STIs, making these groups a priority for public health STI prevention efforts. ${ }^{26}$

In Scotland since 2008, all specialist sexual health settings use a centralised web-based EHR system called the National Sexual Health System. ${ }^{27}$ Access to data contained in the system is highly restricted, and identifiable patient information can only be used when explicit consent from clients is obtained by the care provider at the clinic. ${ }^{27}$ New Zealand currently uses an opt-in strategy for EHR. In planning for an opt-out model, Hunter, Haining and Whiddett conducted a survey where 39\% of patients expressed that they wanted more information, prior discussion or consent before they felt comfortable with their sexual health service records being integrated with EHR. ${ }^{23}$ This has been echoed in another study where clients' acceptability of sharing electronic health information was dependent on building trust in providers and institutions prior to EHR implementation. ${ }^{28}$ Similarly, the results from our study suggest that careful planning to address patient privacy concerns and evaluation of the impacts should be conducted during the implementation and use of EHR. Measures to increase patient knowledge about EHR integration may help normalise the idea of EHRs and improve acceptability; however, patient education strategies in the UK and Scotland had limited success and warrant further

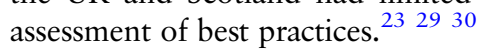

\section{Limitations}

We recognise this study has a number of limitations. The main limitation is that attitudes may not necessarily predict behaviour and, therefore, may not reflect the actual proportion of clients who would avoid STI testing should their health records be integrated within a provincial EHR. However, this study does bring forward client concerns around privacy and information sharing, that should be taken into consideration by programme planners to avoid compromising clients' trust in services if data is shared without their prior knowledge or consent. This could result in unintended consequences for clients, or create barriers to STI and HIV testing. It also underscores the importance of confidential, specialised sexual health services such as those offered at the BCCDC Provincial STI clinic. It is also possible that the way the outcome variable is framed-asking clients if they would be less likely to test-could bias responses towards a negative outcome. The lack of diversity in demographic factors within the study population limited our ability to detect differences among different subgroups, including MSM. This may have been exacerbated by the relatively lower response rate to demographic questions. Only three participants were identified as transgender in this study. As a result, even though gender was a significant variable in our bivariate and multivariate analysis, we are unable to make clear observations on the attitudes of participants who were identified as transgender. Missing data varied by question, with attitudes questions having a range from $0.9 \%$ to $5.5 \%$ missing, while for demographic factors missing data ranged from $4.3 \%$ to $5.5 \%$ of the total possible responses. Missing data were not included in the bivariate analysis or logistic regression model.

In this study, we chose to dichotomise the five-point Likert scale, which grouped neutral responses with negative responses. This may have biased our results by overestimating the number of individuals in disagreement with the survey questions. However, when the bivariate and multivariate analyses were conducted using the five distinct categories, the same variables remained significant, as did the direction of the effect (data not 
shown). Finally, as this study was conducted at one clinic in an urban centre in Vancouver, these findings may not be generalisable to the larger population.

\section{CONCLUSION}

This study assessed the attitudes towards EHR information exchange among clients at the Provincial STI/HIV clinic in Vancouver, BC. A significant number of participants (31.6\%) stated that they would be less likely to test for STIs if their health records were made part of provincial EHR, which appeared to be associated with attitudes of heightened expectations of privacy and limiting access to records beyond the clinic. This raises concerns that information sharing through EHR may deter clients from testing for STIs. Obtaining consent using an opt-in strategy, restrictions on access to STI or HIV clinical data, along with patient education strategies may enable patients to make informed decisions and improve acceptability of EHR, and warrant further investigation. Preserving capacity for accessing STI or HIV testing anonymously or non-nominally becomes increasingly important as EHRs are implemented. The introduction of EHR accessible to multiple external care providers should be considered with caution in STI healthcare settings and should be implemented with an evaluation component to ensure that screening, case detection and treatment are not negatively impacted.

\section{Key messages}

- Health information systems integrating multiple clinical health records into a single provincial record are being implemented in Canada to improve communicable disease control.

- Sharing health information beyond the sexual health clinic may create barriers for clients which could result in avoidance of testing for STIs.

- Clients accessing sexual health services may have increased expectations of privacy and confidentiality which should be considered when implementing health information sharing systems.

\section{Handling editor Jackie A Cassell}

Contributors All authors contributed to study design, data interpretation and generation of conclusions. DT supervised the data acquisition and HP led the data analysis. HP prepared the first draft of the manuscript and all authors contributed to editing and critical analysis of the manuscript and conclusions.

Funding This project did not receive any direct funding, but was operationally supported by the BC Centre for Disease Control.

\section{Competing interests None.}

Patient consent Obtained.

Ethics approval The University of British Columbia research ethics board (H10-02772)

Provenance and peer review Not commissioned; externally peer reviewed.

Data sharing statement Unpublished data on descriptive statistics for all clinic patients during the study period are available upon request and approval by $\mathrm{Dr}$ Gina Ogilvie.

\section{REFERENCES}

1 World Health Organization. The world health report 2007: a safer future: global public health security in the 21st century. 2007. http://www.who.int/whr/2007/ whr07_en.pdf?ua=1 (accessed 5 May 2014).

2 Health Canada. Learning from SARS: Renewal of Public Health in Canada. 2003. http://www.phac-aspc.gc.ca/publicat/sars-sras/pdf/sars-e.pdf (accessed 25 Jul 2014).
3 British Columbia Ministry of Health. eHealth-Faster, safer, better healthcare. Ministry of Health. http://www.health.gov.bc.ca/ehealth/emr.html (accessed 3 Jun 2014).

4 PricewaterhouseCoopers Canada. The emerging benefits of electronic medical record use in community-based care. 2013. https://www.infoway-inforoute.ca/index. php/component/docman/doc_download/1395-the-emerging-benefits-of-electronicmedical-record-use-in-community-based-care-full-report (accessed 25 Jul 2014).

5 Fairley CK, Vodstrcil LA, Huffam S, et al. Evaluation of Electronic Medical Record (EMR) at Large Urban Primary Care Sexual Health Centre. PLOS ONE 2013;8: e60636.

6 IBM Corporation. Panorama: Pan-Canadian Public Health Communicable Disease Surveillance and Management. 2009. http://www-03.ibm.com/industries/ca/en/ healthcare/files/panorama_application_overview_final.pdf (accessed 3 Jun 2014).

7 Canada Health Infoway. Public health surveillance: developing a pan-Canadian solution to protect Canadians. 2013. https://www.infoway-inforoute.ca/index.php/ progress-in-canada/experiences-and-perspectives/public-health-surveillancedeveloping-a-pan-canadian-solution-to-protect-canadians (accessed 3 Jun 2014).

8 British Columbia Ministry of Health. eHealth: Public Health Information Project (PHIP). http://www.health.gov.bc.ca/ehealth/phip.html (accessed 3 Jun 2014).

9 Ryan KM, Boustead AJ. Universal electronic health records: a qualitative study of lay perspectives. NZ Fam Physician 2004;31:149-54.

10 King T, Brankovic L, Gillard P. Perspectives of Australian adults about protecting the privacy of their health information in statistical databases. Int $J$ Med Inform 2012:81:279-89.

11 Chhanabhai $P$, Holt $A$. Consumers are ready to accept the transition to online and electronic records if they can be assured of the security measures. Med Gen Med 2007:9:8

12 Fairley $C K$, Williams $\mathrm{H}$, Lee DM, et al. A plea for more research on access to sexual health services. Int J STD AIDS 2007;18:75-6.

13 Van Look PFA, Heggenhougen HK, Quah SR. Sexual and reproductive health: a public health perspective. Elsevier, 2011

14 Masaro CL, Johnson J, Chabot C, et al. STI service delivery in British Columbia, Canada; providers' views of their service to youth. BMC Health Serv Res 2012;12:1-10.

15 Bungay V, Gilbert M, Mak S, et al. Nursing Practice in Sexually Transmitted Infections and HIV in British Columbia. 2010. http://www.nursing.ubc.ca/pdfs/ EnvironmentalScan1102.pdf (accessed 25 Jul 2014).

16 Balfe M, Brugha $\mathrm{R}, \mathrm{O}^{\prime}$ Donovan D, et al. Triggers of self-conscious emotions in the sexually transmitted infection testing process. BMC Res Notes 2010;3:229.

17 Balfe M, Brugha R. What prompts young adults in Ireland to attend health services for STI testing? BMC Public Health 2009;9:1-10.

18 Hambly S, Luzzi G. Sexual health services-a patient preference survey. Int J STD AIDS 2006;17:372-4.

19 Thomas N, Murray E, Rogstad KE. Confidentiality is essential if young people are to access sexual health services. Int J STD AIDS 2006;17:525-29.

20 Public Health Agency of Canada. The Chief Public Health Officer's Report on the State of Public Health in Canada, 2013. 2013. http://www.phac-aspc.gc.ca/ cphorsphc-respcacsp/2013/sti-its-eng.php\#a1 (accessed 5 May 2014).

21 Francis JJ, Eccles M, Johnston M, et al. Constructing Questionnaires based on the theory of planned behaviour: a manual for health services researchers. Quality of Life and Management of Living Resources, 2004; University of Newcastle. http:// pages.bangor.ac.uk/ pes004/exercise_psych/downloads/tpb_manual.pdf (accessed 6 Jun 2014).

22 Hosmer DW, Lemeshow S, Sturdivant RX. Wiley series in probability and statistics: applied logistic regression, 3rd edn. New York, NY, USA: Wiley, 2013.

23 Hunter I, Haining Ede G, Whiddett R. Increased electronic information sharing by sexual health services: Confidentiality and consent. Health Inform J 2014;20:3-12.

24 Gilbert M, Salway Hottes T, Kerr T, et al. Factors associated with intention to use internet-based testing for sexually transmitted infections among men who have sex with men. J Med Internet Res 2013:15:e254.

25 Kennedy EP, MacPhee C. Access to confidential sexual health services. Canadian Nurse 2006:102:29-31.

26 BC Centre for Disease Control. STI in British Columbia: Annual Surveillance Report 2012. 2012. http://www.bccdc.ca/NR/rdonlyres/3485757D-A8DC-417C-8422521D6C911B2D/0/STI_Annual_Report_2011_20130327.pdf (accessed 25 Jul 2014).

27 McDaid L, Docherty S, Winter AJ. Review of the National Sexual Health System (NaSH) in Scotland: the potential for sexual health research. MRC/CSO Social and Public Health Sciences Unit. Occasional Paper no 24. Nov 2013

28 Maiorana A, Steward WT, Koester KA, et al. Trust, confidentiality, and the acceptability of sharing HIV-related patient data: lessons learned from a mixed methods study about Health Information Exchanges. Implement Sci 2012;7:1-14.

29 Bratan T, Stramer K, Greenhalgh T. 'Never heard of it'- understanding the public's lack of awareness of a new electronic patient record. Health Expectations 2010;13:379-91.

30 Johnstone C, McCartney G. A patient survey assessing the awareness and acceptability of the emergency care summary and its consent model in Scotland. Perspect Health Inform Manag 2010;7:1e. 